\title{
Russian Companies in Autumn 2020: Activities in the COVID-19 Pandemic and Views on the Transition to the Best Available Technologies (BAT)
}

\author{
D. B. Kuvalin ${ }^{a}$, Yu. V. Zinchenko ${ }^{a, *}$, and P. A. Lavrinenko ${ }^{a}$ \\ ${ }^{a}$ Institute of Economic Forecasting, Russian Academy of Sciences, Moscow, Russia \\ *e-mail:yuvzinch@gmail.com \\ Received January 13, 2021; revised January 15, 2021; accepted January 18, 2021
}

\begin{abstract}
The paper analyzes and comments on the results of a regular survey of Russian enterprises in the real sector, which was conducted by the Institute of Economic Forecasting of the Russian Academy of Sciences. Information on the impact of the coronavirus pandemic on the activities of domestic enterprises is provided. The opinions of enterprises on the severity of various macroeconomic problems in Russia are reflected. The data on the relations between Russian enterprises and banks are presented. The degree of demand of Russian enterprises in the modernization of production is determined. Information on purchases of domestic and foreign equipment in Russia is considered. The assessments of enterprises regarding the quality of Russian machinery and equipment are given. The data on delays in the supply of raw materials and components are presented. The opinions of enterprises on the implementation of the best available technologies (BAT) in Russia are reflected.
\end{abstract}

Keywords: economic consequences of the COVID-19 pandemic, enterprise behavior, enterprise survey, enterprise lending, quality of Russian technology, best available technologies

DOI: $10.1134 / \mathrm{S} 1075700721030084$

In the second half of 2020, the COVID-19 pandemic continued to pose serious problems for the Russian economy. Meanwhile, the weakening of quarantine measures, the actions of the Russian authorities to support the population and enterprises, a certain revival in international markets and some relaxation of the national macrofinancial policy by the end of the year made it possible to significantly reduce the severity of the economic crisis in the country.

While Russia's GDP fell by about $8 \%$ in the most acute phase of the crisis in the second quarter of 2020 compared to the same period in 2019 , the decline in GDP should not exceed $3.8-4.2 \%$ by the end of the year in the opinion of various experts [1-3]. At the same time, according to preliminary estimates of the Federal State Statistics Service, the volume of industrial production for 11 months of 2020 in relation to

Table 1. Answers to the question: "Has your enterprise suffered from the events related to the coronavirus pandemic?" (total of answers $=100 \%$ )

\begin{tabular}{l|c|c|c}
\hline \multicolumn{1}{c|}{ Period } & Yes & No & \multicolumn{1}{c}{$\begin{array}{c}\text { No, but it may } \\
\text { suffer in the future }\end{array}$} \\
\hline April-May 2020 & 73.60 & 4.80 & 21.60 \\
November-December 2020 & 69.12 & 11.03 & 19.85 \\
\hline
\end{tabular}

the same period of 2019, freight turnover of transport, and the volume of paid services to the population decreased by $3.0 \%, 5.4 \%$, and $17.7 \%$, respectively. Meanwhile, the volume of production in agriculture increased by $1.5 \%$. The volume of investments in fixed assets for nine months of 2020 fell by $4.1 \%$ [4].

The complexity and inconstancy of the situation in the Russian economy are clearly visible in the data of the survey of Russian enterprises, which was conducted by the Institute of National Economic Forecasting of the Russian Academy of Sciences in November-December $2020^{1}$. For example, while in April-May $202073.60 \%$ of the respondents said that their enterprise was affected by the events associated with the coronavirus pandemic, in NovemberDecember there were fewer such answers-69.12\%. At the same time, there was an increase in the number of enterprises reporting that they were not affected by the pandemic. The share of such answers increased from $4.80 \%$ in April-May 2020 to $11.03 \%$ in November-

\footnotetext{
${ }^{1}$ The survey involved 139 enterprises (power industry; water supply; ferrous and non-ferrous metallurgy; chemistry; mechanical engineering; building materials industry; forestry, woodworking and pulp and paper industries; light, food, pharmaceutical and printing industries; agriculture; construction; transport; vehicle repairs; health care; trade; public catering) from 58 regions of Russia.
} 
Table 2. Answers to the question: "What has happened to the sales volume of your enterprise?" (total of answers $=100 \%)$

\begin{tabular}{|c|c|c|c|c|c|c|c|}
\hline \multirow[b]{3}{*}{ Period } & \multicolumn{7}{|c|}{ Sales volume } \\
\hline & \multirow[b]{2}{*}{$\begin{array}{l}\text { it has } \\
\text { increased }\end{array}$} & \multirow[b]{2}{*}{$\begin{array}{c}\text { it has remained } \\
\text { at the same } \\
\text { level }\end{array}$} & \multicolumn{5}{|c|}{ It has decreased } \\
\hline & & & by 10 & by $11-20 \%$ & by $21-50 \%$ & $\begin{array}{l}\text { more than } \\
\text { by } 50 \%\end{array}$ & $\begin{array}{l}\text { down to } 0 \% \text {, } \\
\text { the enterprise has } \\
\text { almost closed }\end{array}$ \\
\hline April-May 2020 & 3.20 & 15.90 & 15.90 & 23.00 & 22.20 & 15.90 & 4.00 \\
\hline $\begin{array}{l}\text { November- } \\
\text { December } 2020\end{array}$ & 7.91 & 19.42 & 26.62 & 17.99 & 20.86 & 5.76 & 1.44 \\
\hline
\end{tabular}

Table 3. Answers to the question: "Was your business able to take advantage of the support measures promised by the federal authorities in connection with the coronavirus pandemic?" (total of answers $=100 \%$ )

\begin{tabular}{l|r|r|c}
\hline \multicolumn{1}{c|}{ Period } & Yes & No & $\begin{array}{l}\text { No, but it intends to } \\
\text { take advantage of this } \\
\text { support in the future }\end{array}$ \\
\hline April-May 2020 & 9.00 & 70.50 & 20.50 \\
November-December & 24.82 & 68.61 & 6.57 \\
2020 & & \\
\hline
\end{tabular}

December 2020 (Table 1). In addition, the proportion of enterprises that reported growth or stability of their sales volumes increased by the end of the year, and the proportion of enterprises that experienced a deep decline in sales volumes (over 50\%) significantly decreased. In particular, the share of reports about a growth in sales volumes increased from $3.20 \%$ in April-May 2020 to $7.91 \%$ in November-December 2020. At the same time, the share of answers about a drop in sales volumes by more than $50 \%$ decreased from $15.90 \%$ in April-May 2020 to 5.76\% in November-December 2020 (Table 2). Such shifts in the structure of answers confirm that the situation improved in some areas of the Russian economy in the second half of the year.

One of the factors that influenced the economic situation for the better was the support of enterprises from the state. The variety of forms of this support and their relatively quick launch into action made it possible to cover a fairly wide range of economic activities and enterprises. As a result, the share of enterprises that were able to take advantage of support measures from the federal authorities increased from $9.00 \%$ in April-May 2020 to $24.82 \%$ in November-December 2020. However, the share of enterprises that did not receive such support changed little-from $70.50 \%$ in April-May 2020 to $68.61 \%$ in November-December 2020 (Table 3).

In other words, most of the Russian enterprises affected by the crisis associated with the pandemic had to make do on their own. This is probably why Russian enterprises as a whole were very cautious in assessing their market prospects. Only $5.76 \%$ of the respondents expected an increase in sales volumes in the next 12 months in November-December 2020. Even in April-May 2020, the share of such respondents was higher at $14.20 \%$. Admittedly, the share of enterprises that believed that the sales volume would not fall and would remain approximately at the same level increased noticeably, from 29.90\% in April-May 2020 to $46.04 \%$ in November-December 2020. However, the share of enterprises that expected a reduction in sales volumes did not decrease by the end of the year. In April-May 2020 it was $27.60 \%$, and in NovemberDecember 2020 it was $28.78 \%$ (Table 4). Thus, enterprises as a whole do not expect a quick recovery of the Russian economy from the current crisis. However, such cautious views of enterprises on the future were also characteristic of all previous crises that had taken place in the Russian economy. Moreover, enterprises were clearly pessimistic about the near future even in situations when the national economy was actually rather quickly (as in the spring of 2009) overcoming the consequences of the crisis.

At the same time, it should be noted that the crisis phenomena generated by the pandemic had relatively little effect on the views of domestic enterprises about

Table 4. Answers to the question: "What, according to your estimates, will happen with the sales volume of your enterprise in the nearest (1-2 months) perspective?" (total of answers $=100 \%$ ).

\begin{tabular}{l|c|c|c|c}
\hline \multicolumn{1}{c|}{ Period } & $\begin{array}{c}\text { The sales volume } \\
\text { will begin to grow }\end{array}$ & $\begin{array}{c}\text { The sales volume will } \\
\text { remain at approximately } \\
\text { the same level }\end{array}$ & $\begin{array}{c}\text { The sales volume will } \\
\text { continue to decrease }\end{array}$ & $\begin{array}{c}\text { It is difficult to say, } \\
\text { the level of uncertainty } \\
\text { in the market is very high }\end{array}$ \\
\hline April-May 2020 & 14.20 & 29.90 & 27.60 & 28.30 \\
November-December 2020 & 5.76 & 46.04 & 28.78 & 19.42 \\
\hline
\end{tabular}




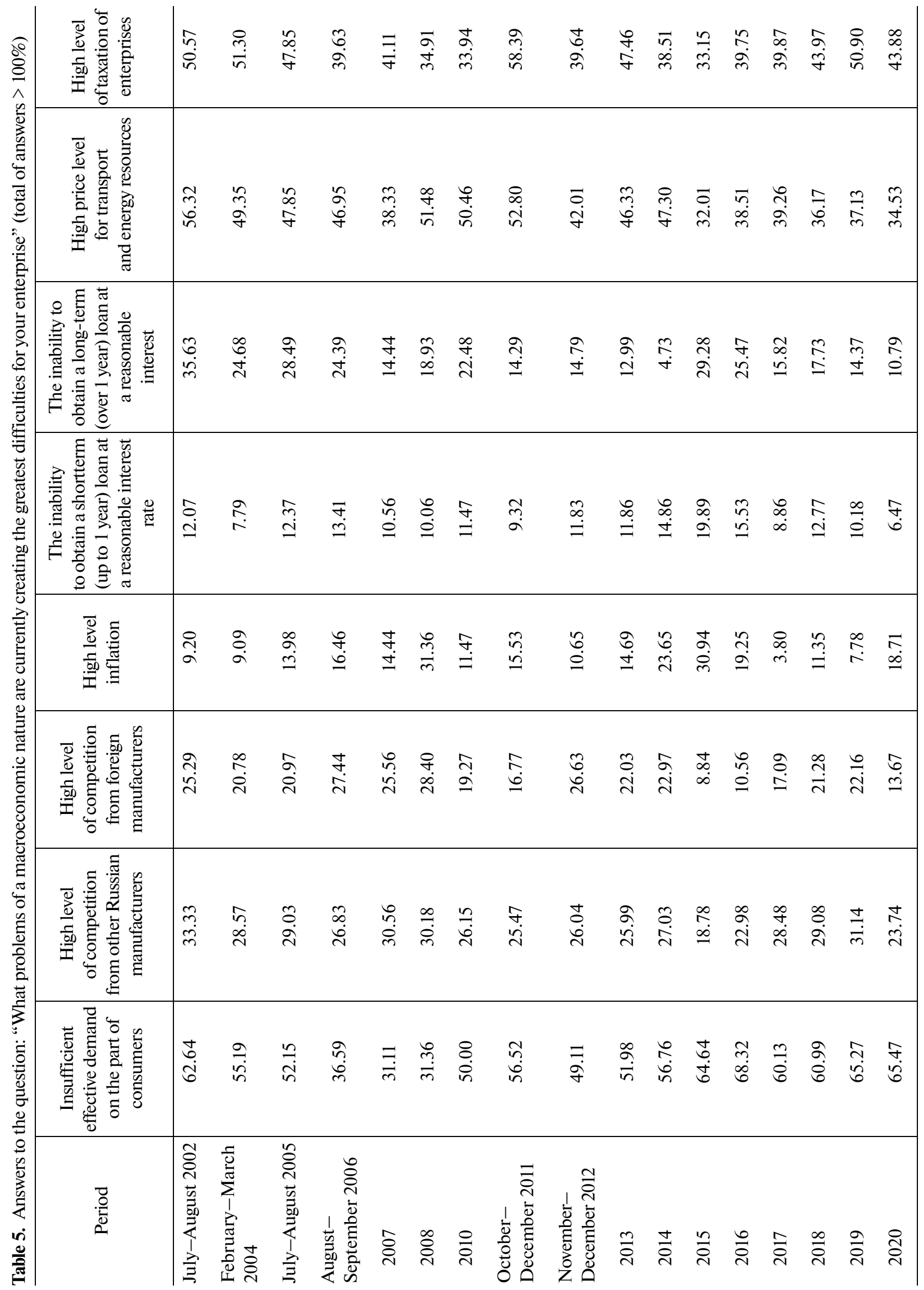




\begin{tabular}{|c|c|c|c|c|c|c|c|c|c|c|c|c|c|c|c|c|c|}
\hline $\begin{array}{l}\bar{\Xi} \\
\tilde{\Xi}\end{array}$ & గై & $\stackrel{8}{0}$ & $\bar{\sigma}$ & 중 & $\begin{array}{l}a \\
\infty \\
\infty\end{array}$ & $\stackrel{?}{\stackrel{f}{d}}$ & $\stackrel{\infty}{\stackrel{n}{f}}$ & $\tilde{\check{\sigma}}$ & $\stackrel{\Re}{\stackrel{f}{f}}$ & 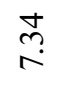 & $\stackrel{\infty}{\stackrel{\infty}{6}}$ & 号 & $\hat{a}$ & $\begin{array}{l}\stackrel{8}{0} \\
i n\end{array}$ & $\stackrel{\text { aे }}{\text {. }}$ & $\stackrel{2}{\stackrel{2}{r}}$ & $\stackrel{\text { ㄱ. }}{i}$ \\
\hline 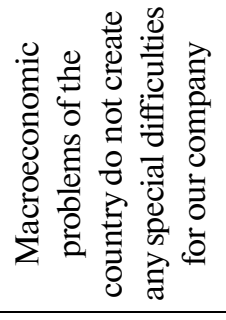 & $\stackrel{8}{\circ}$ & ¿n & 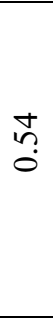 & $\stackrel{\text { Iิ }}{\text { S }}$ & $\stackrel{n}{n}$ & $\stackrel{8}{\circ}$ & $\stackrel{0}{!}$ & $\stackrel{8}{\circ}$ & $\stackrel{\infty}{\stackrel{\sim}{\rightarrow}}$ & $\stackrel{9}{=}$ & $\stackrel{?}{i}$ & : & $\stackrel{\unlhd}{I}$ & $\underset{m}{\stackrel{0}{m}}$ & $\stackrel{n}{n}$ & $\stackrel{\infty}{\rightarrow}$ & $\underset{i}{\stackrel{0}{i}}$ \\
\hline 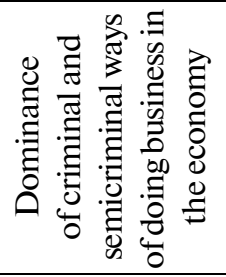 & $\stackrel{\stackrel{+}{m}}{\stackrel{\rho}{\varrho}}$ & ఫुे & $\stackrel{\infty}{i}$ & $\stackrel{\Omega}{r}$ & 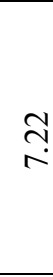 & $\stackrel{m}{i}$ & f̊. & $\stackrel{m}{m}$ & $\underset{\sim}{\stackrel{\leftrightarrow}{0}}$ & $\underset{\sim}{\sim}$ & $\underset{i n}{F}$ & : & $\underset{m}{\vec{m}}$ & $\underset{i}{\stackrel{R}{i n}}$ & $\stackrel{n}{n}$ & $\stackrel{\vartheta}{\vec{\gamma}}$ & $\tilde{\sim}$ \\
\hline 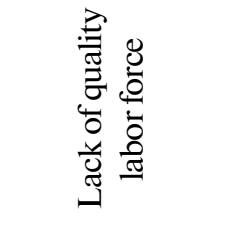 & $\begin{array}{l}\stackrel{+}{2} \\
\stackrel{2}{g}\end{array}$ & $\stackrel{\bar{m}}{\dot{m}}$ & $\begin{array}{l}\infty \\
\infty \\
\stackrel{\sim}{0}\end{array}$ & $\begin{array}{l}\tilde{\delta} \\
\dot{m}\end{array}$ & $\begin{array}{l}\text { } \\
\stackrel{n}{n}\end{array}$ & $\begin{array}{l}\text { ర్d } \\
\text { in }\end{array}$ & $\begin{array}{l}\text { बे } \\
\text { के }\end{array}$ & $\begin{array}{l}\vec{\sigma} \\
\vec{F}\end{array}$ & 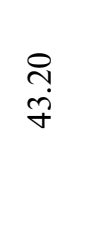 & $\begin{array}{l}n \\
\stackrel{n}{n} \\
\stackrel{n}{n}\end{array}$ & $\begin{array}{l}\vec{\infty} \\
\dot{j} \\
\dot{m}\end{array}$ & $\begin{array}{l}\bar{m} \\
\stackrel{i}{d}\end{array}$ & 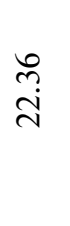 & $\begin{array}{l}\infty \\
\stackrel{\infty}{\sim} \\
\stackrel{\sim}{\sim}\end{array}$ & $\begin{array}{l}\text { త్ర } \\
\text { లె }\end{array}$ & 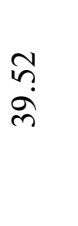 & $\begin{array}{l}\text { ते } \\
\text { के }\end{array}$ \\
\hline 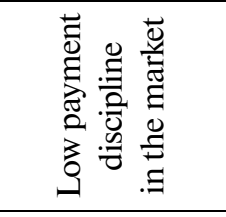 & $\begin{array}{l}\text { aे } \\
\stackrel{i}{~}\end{array}$ & 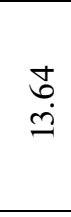 & $\begin{array}{l}\stackrel{m}{a} \\
\stackrel{g}{g}\end{array}$ & İ & $\stackrel{8}{\circ}$ & $\begin{array}{l}\underset{\infty}{\sim} \\
\infty\end{array}$ & $\begin{array}{l}\stackrel{8}{\circ} \\
\stackrel{\leftrightarrow}{\circ}\end{array}$ & $\begin{array}{l}\bar{\sigma} \\
\dot{J}\end{array}$ & $\begin{array}{l}\tilde{\sigma} \\
\stackrel{\sim}{\sim}\end{array}$ & 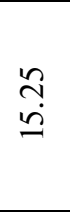 & $\underset{\tilde{N}}{ }$ & 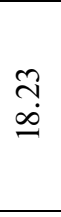 & $\stackrel{\infty}{\exists}$ & $\begin{array}{l}\stackrel{0}{n} \\
\stackrel{?}{ \pm}\end{array}$ & 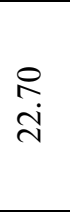 & 获 & ڤn \\
\hline 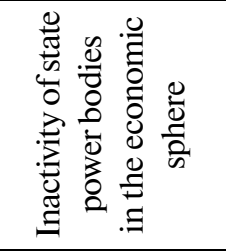 & $\begin{array}{l}\stackrel{+}{\infty} \\
\stackrel{\sim}{\sim}\end{array}$ & $\begin{array}{l}\tilde{\infty} \\
\stackrel{\infty}{\infty}\end{array}$ & $\begin{array}{l}\stackrel{m}{m} \\
\stackrel{2}{2}\end{array}$ & 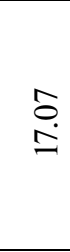 & $\stackrel{\text { }}{\stackrel{\sim}{i}}$ & $\stackrel{\sim}{\stackrel{\sim}{\Lambda}}$ & $\stackrel{\text { f }}{\subseteq}$ & $\begin{array}{l}\text { ñ } \\
\stackrel{n}{0}\end{array}$ & $\underline{\hat{n}}$ & $\begin{array}{l}\stackrel{8}{\mathrm{i}} \\
\text { in }\end{array}$ & $\stackrel{\tilde{n}}{\cong}$ & $\begin{array}{l}\stackrel{\infty}{\infty} \\
\stackrel{\infty}{g}\end{array}$ & $\stackrel{n}{\underline{n}}$ & $\begin{array}{l}\text { ర్d } \\
\stackrel{\sigma}{\sigma}\end{array}$ & $\begin{array}{l}8 \\
\stackrel{b}{a} \\
\end{array}$ & $\underline{\underline{0}}$ & $\stackrel{\overbrace{}}{I}$ \\
\hline 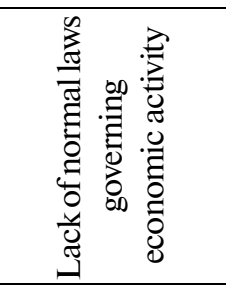 & $\stackrel{\vec{\sim}}{\stackrel{d}{d}}$ & $\begin{array}{l}\infty \\
\infty \\
\stackrel{0}{0}\end{array}$ & $\hat{\hat{d}}$ & 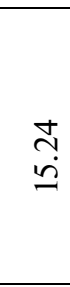 & $\underset{\stackrel{J}{+}}{\stackrel{f}{J}}$ & f. & $\stackrel{\infty}{\stackrel{\sim}{\pi}}$ & 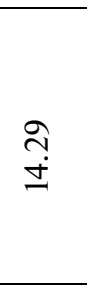 & $\stackrel{0}{\stackrel{0}{I}}$ & 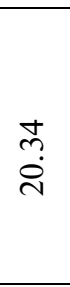 & $\begin{array}{l}\stackrel{ \pm}{\infty} \\
\stackrel{\bigcup}{\beth}\end{array}$ & $\begin{array}{l}\tilde{J} \\
\dot{I}\end{array}$ & $\stackrel{\text { }}{=}$ & $\begin{array}{l}\stackrel{m}{m} \\
\stackrel{\infty}{\infty}\end{array}$ & $\begin{array}{l}8 \\
\stackrel{0}{0} \\
\end{array}$ & 旁 & $\stackrel{\partial}{\varrho}$ \\
\hline 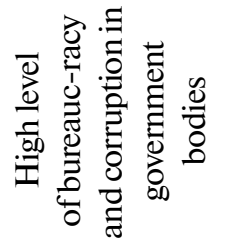 & $\begin{array}{l}\stackrel{+}{\infty} \\
\stackrel{\sim}{\sim}\end{array}$ & $\begin{array}{l}\infty \\
\stackrel{+}{\sim} \\
\dot{\sim}\end{array}$ & $\stackrel{\Re}{\stackrel{d}{d}}$ & $\begin{array}{l}0 \\
\stackrel{n}{n} \\
\text { N }\end{array}$ & 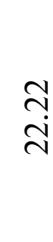 & $\overrightarrow{\hat{d}}$ & $\begin{array}{l}\infty \\
\infty \\
\tilde{\sim} \\
\dot{\sim}\end{array}$ & $\begin{array}{l}\text { in } \\
\text { ते }\end{array}$ & $\begin{array}{l}\infty \\
\stackrel{\sim}{\sim}\end{array}$ & $\begin{array}{l}\infty \\
\stackrel{\infty}{\infty} \\
\stackrel{\infty}{0}\end{array}$ & $\underset{\tilde{N}}{ }$ & $\begin{array}{l}\stackrel{ \pm}{+} \\
\stackrel{+}{ \pm}\end{array}$ & $\begin{array}{l}\stackrel{ \pm}{\Delta} \\
\stackrel{\Xi}{a}\end{array}$ & $\begin{array}{l}\tilde{\Omega} \\
\tilde{\Omega}\end{array}$ & 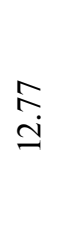 & $\begin{array}{l}\hat{\theta} \\
\dot{g}\end{array}$ & $\stackrel{\vec{n}}{=}$ \\
\hline $\begin{array}{l}\overrightarrow{0} \\
. \overline{0} \\
0\end{array}$ & 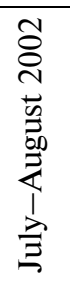 & 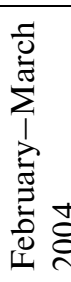 & 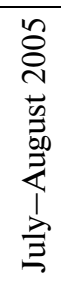 & 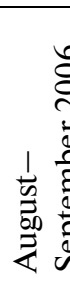 & & $\stackrel{\infty}{0}$ & 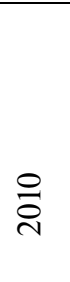 & 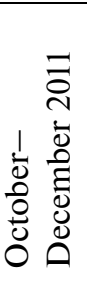 & 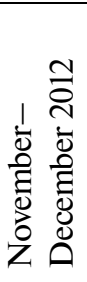 & $\stackrel{m}{\vec{N}}$ & $\stackrel{ \pm}{\stackrel{\sim}{~}}$ & $\stackrel{n}{\grave{N}}$ & 䒕 & 亏े & $\stackrel{\infty}{\grave{\sim}}$ & Әे & ్ָరి \\
\hline
\end{tabular}


Table 6. Answers to the question: "How, in your opinion, has banks fulfilling their obligations to enterprises changed over the past year?" (total of answers $=100 \%$ )

\begin{tabular}{l|c|c|c}
\hline \multicolumn{1}{c|}{ Period } & It has improved & It has remained at the same level & It has worsened \\
\hline August-September 2010 & 20.66 & 72.30 & 7.04 \\
October-December 2011 & 14.19 & 78.71 & 7.10 \\
November-December 2012 & 13.41 & 78.05 & 8.54 \\
November-December 2013 & 10.40 & 80.35 & 9.25 \\
November-December 2014 & 6.38 & 78.17 & 15.50 \\
November-December 2015 & 3.37 & 76.97 & 19.66 \\
November-December 2016 & 6.29 & 77.99 & 15.72 \\
November-December 2017 & 10.26 & 76.28 & 13.46 \\
November-December 2018 & 13.48 & 78.72 & 7.80 \\
November-December 2019 & 13.33 & 79.40 & 7.27 \\
November-December 2020 & 9.63 & 80.74 & 9.63 \\
\hline
\end{tabular}

the severity of macroeconomic problems in Russia. As in previous surveys, enterprises most often indicated insufficient effective demand among the most acute problems at the end of 2020 in $65.69 \%$ of answers. But this is exactly the same share of answers as in the precrisis 2019. Moreover, over the year there was a decrease in the frequency of complaints about problems such as a high level of competition with other Russian manufacturers (31.14\% of answers in 2019 and $23.74 \%$ of answers in 2020), a high level of competition with foreign manufacturers $(22.16 \%$ in 2019 and $13.67 \%$ in 2020 ), the inability to obtain a short-term loan (10.18\% in 2019 and $6.47 \%$ in 2020), and the inability to obtain a long-term loan (14.37\% in 2019 and $10.79 \%$ in 2020). The frequency of complaints about the high level of taxation also decreased from $50.90 \%$ of answers in 2019 to $43.88 \%$ of answers in 2020. It is likely that this positive shift is associated with tax incentives that were provided to Russian small and medium enterprises in the second quarter of 2020 , as well as a number of large enterprises from the hardest hit industries. In addition, it should be noted that the proportion of complaints about a high level of bureaucracy and corruption in government bodies in 2020 turned out to be the lowest for the entire period of the surveys, $11.51 \%$ (Table 5).

A distinctive feature of the economic crisis in 2020 was the relative stability in the financial and banking sector. Unlike the crises of 1998, 2008, and 20142015 , there were no significant disruptions in the payment system, bursts of inflation, or a sharp increase in interest rates in Russia. As the survey data show, relations between Russian enterprises and banks were also quite stable and generally avoided the negative impact of the crisis. In particular, the overwhelming number of respondents-80.74\%-answered that banks fulfilled their obligations in 2020 at the same level. At the same time, the shares of answers about the improve- ment and deterioration of banks' behavior turned out to be the same (Table 6).

In addition, it should be noted that the share of answers about the absence of deliberate delays in payments by banks increased again in 2020. As a result, this share reached its maximum level since 2001 at $84.78 \%$ (Table 7).

However, the depth of interaction between Russian enterprises and banks still leaves much to be desired. In particular, the total share of enterprises receiving loans from banks for the implementation of investment projects amounted to only $20.29 \%$ in 2020 . This is significantly less than, for example, in 2011-2012 (Table 8).

Bringing the Russian economy out of the crisis requires efforts in a number of areas. One of these areas is the technological modernization of production [5-9]. As the survey data show, the current eco-

Table 7. Answers to the question: "Has your company faced a deliberate delay in payments by banks over the past year?" (total of answers $=100 \%$ )

\begin{tabular}{l|c|c|c}
\hline \multicolumn{1}{c|}{ Period } & Yes & No & $\begin{array}{c}\text { It is difficult } \\
\text { to judge }\end{array}$ \\
\hline August-September 2010 & 7.55 & 76.42 & 16.03 \\
October-December 2011 & 4.52 & 71.61 & 23.87 \\
November-December 2012 & 4.82 & 77.11 & 18.07 \\
November-December 2013 & 5.23 & 76.74 & 18.03 \\
November-December 2014 & 5.67 & 78.72 & 15.61 \\
November-December 2015 & 11.24 & 75.28 & 13.48 \\
November-December 2016 & 5.63 & 76.25 & 18.12 \\
November-December 2017 & 7.74 & 76.13 & 16.13 \\
November-December 2018 & 7.04 & 79.58 & 13.38 \\
November-December 2019 & 9.03 & 79.52 & 11.45 \\
November-December 2020 & 5.07 & 84.78 & 10.14 \\
\hline
\end{tabular}


Table 8. Answers to the question: "What is the cooperation of your enterprise with Russian banks at the present time?" (total of answers $=100 \%$ )

\begin{tabular}{l|c|c|c|c}
\hline \multicolumn{1}{c|}{ Period } & $\begin{array}{c}\text { Cooperation } \\
\text { is limited only } \\
\text { to settlement } \\
\text { and cash services }\end{array}$ & $\begin{array}{c}\text { Settlement } \\
\text { and cash services } \\
\text { and lending } \\
\text { of turnover means }\end{array}$ & $\begin{array}{c}\text { Settlement and cash } \\
\text { services, lending of turnover } \\
\text { means and lending } \\
\text { of investment projects } \\
\text { for a period of 1-2 years }\end{array}$ & $\begin{array}{c}\text { Settlement and cash services, } \\
\text { lending of turnover means } \\
\text { and lending of investment } \\
\text { projects for a period } \\
\text { of 3-5 years and more }\end{array}$ \\
\hline August-September 2010 & 40.38 & 35.68 & 9.86 & 14.08 \\
October-December 2011 & 43.71 & 30.46 & 13.91 & 11.92 \\
November-December 2012 & 41.57 & 33.13 & 11.45 & 13.85 \\
November-December 2013 & 50.57 & 27.84 & 9.09 & 12.50 \\
November-December 2014 & 41.50 & 34.01 & 10.88 & 13.61 \\
November-December 2015 & 47.75 & 33.15 & 6.18 & 12.92 \\
November-December 2016 & 50.94 & 31.45 & 6.92 & 10.69 \\
November-December 2017 & 51.61 & 27.75 & 6.45 & 14.19 \\
November-December 2018 & 52.48 & 34.04 & 2.13 & 11.35 \\
November-December 2019 & 46.38 & 35.54 & 4.22 & 13.86 \\
November-December 2020 & 47.10 & 32.61 & 6.52 & 13.77 \\
\hline
\end{tabular}

Table 9. Answers to the question: "How great is your enterprise's need for modernization of production and technological innovations at the moment?" (total of answers $=100 \%$ )

\begin{tabular}{l|c|c|c}
\hline \multicolumn{1}{c|}{ Period } & $\begin{array}{c}\text { Special modernization is not } \\
\text { required; the renewal will be } \\
\text { made as the need arises } \\
\text { (renewal of a part of equipment, } \\
\text { structures, communications, } \\
\text { some technological processes) }\end{array}$ & $\begin{array}{c}\text { A radical modernization } \\
\text { is required }\end{array}$ \\
\hline March-April 2011 & 21.21 & 58.08 & 20.71 \\
November-December 2012 & 21.08 & 57.23 & 21.69 \\
April-May 2014 & 15.76 & 55.15 & 29.09 \\
November-December 2015 & 26.26 & 58.10 & 15.64 \\
April-May 2017 & 23.97 & 61.64 & 14.39 \\
November-December 2018 & 26.76 & 57.04 & 16.20 \\
November-December 2020 & 25.36 & 63.04 & 11.59 \\
\hline
\end{tabular}

nomic crisis has somewhat changed the views of enterprises regarding the need to modernize production. About a quarter of the surveyed enterprises (and this is almost the maximum for the period of the survey) believe that they do not need modernization at the moment; about two-thirds of the respondents think that partial modernization is sufficient, and only $11.59 \%$-less than ever before-believe that they need a radical technological modernization (Table 9). Apparently, such a decrease in the need for modernization efforts is associated with a rather pessimistic view of enterprises on the medium-term prospects of the Russian economy. Why must money be spent on modernization if demand for additional products is either falling or growing very slowly?

However, regardless of the need to modernize production, the enterprises' own resources, which they can spend on technological innovations, remain generally insufficient. Only $13.43 \%$ of the respondents reported that the current volume of investments allowed them to carry out a full modernization. At the same time, another $35.07 \%$ of the respondents can carry out partial modernization. Thus, about half of Russian enterprises cannot finance the modernization of production and the introduction of technological innovations as before. This state of affairs established at the end of the 2000s and has barely changed since then (Table 10).

A key element of technological modernization is the purchase of machinery and equipment $[10,11]$. Under the conditions when sanctions restrictions are overlapped on a severe economic crisis, it is very important that the competitiveness of domestic technology be gradually growing. On the one hand, this 
Table 10. Answers to the question: "Does the current level of production investments of your enterprise provide a solution to the problem of a full modernization of production?", \% (total of answers $=100 \%$ )

\begin{tabular}{l|c|c|c|c}
\hline \multicolumn{1}{|c|}{ Period } & $\begin{array}{c}\text { Yes, it provides } \\
\text { quite fully }\end{array}$ & $\begin{array}{c}\text { It is able } \\
\text { to provide only } \\
\text { some partial } \\
\text { improvements }\end{array}$ & $\begin{array}{c}\text { It is able to maintain } \\
\text { production at the existing } \\
\text { technological level and } \\
\text { no more }\end{array}$ & $\begin{array}{c}\text { It does not even ensure } \\
\text { the preservation of the } \\
\text { existing technological } \\
\text { level of production }\end{array}$ \\
\hline March-April 2011 & 11.73 & 34.69 & 34.69 & 18.89 \\
November-December 2012 & 18.40 & 28.22 & 35.58 & 17.80 \\
April-May 2014 & 15.43 & 30.86 & 29.63 & 24.08 \\
November-December 2015 & 11.36 & 32.95 & 38.64 & 17.05 \\
April-May 2017 & 15.86 & 24.14 & 43.45 & 16.55 \\
November-December 2018 & 20.00 & 29.63 & 34.07 & 16.30 \\
November-December 2020 & 13.43 & 35.07 & 41.04 & 10.45 \\
\hline
\end{tabular}

Table 11. Answers to the question: "What machinery and equipment has your company purchased during the last 2-3 years?" (total of answers > 100\%)

\begin{tabular}{l|c|c|c|c|c|c}
\hline \multicolumn{1}{c|}{ Period } & $\begin{array}{c}\text { Machinery } \\
\text { and equipment } \\
\text { of Russian } \\
\text { production, new }\end{array}$ & $\begin{array}{c}\text { Machinery } \\
\text { and equipment } \\
\text { of Russian } \\
\text { production, used }\end{array}$ & $\begin{array}{c}\text { Machinery } \\
\text { and equipment } \\
\text { produced } \\
\text { in the CIS } \\
\text { countries, new }\end{array}$ & $\begin{array}{c}\text { Machinery } \\
\text { and equipment } \\
\text { produced in the } \\
\text { CIS countries, } \\
\text { used }\end{array}$ & $\begin{array}{c}\text { Machinery and } \\
\text { equipment } \\
\text { produced in the } \\
\text { far abroad, new }\end{array}$ & $\begin{array}{c}\text { Machinery and } \\
\text { equipment } \\
\text { produced in the } \\
\text { far abroad, used }\end{array}$ \\
\hline $\begin{array}{l}\text { February- } \\
\text { March 2010 }\end{array}$ & 62.89 & 15.09 & 15.72 & 1.89 & 62.29 & 13.84 \\
October- & 64.19 & 17.57 & 10.81 & 1.35 & 68.92 & 11.49 \\
$\begin{array}{l}\text { December 2011 } \\
\text { April-May 2013 }\end{array}$ & 47.97 & 13.51 & 11.49 & 0.68 & 70.27 & 11.49 \\
$\begin{array}{l}\text { November- } \\
\text { December 2014 }\end{array}$ & 56.72 & 17.16 & 13.43 & 2.99 & 64.18 & 10.45 \\
$\begin{array}{l}\text { April-May 2016 } \\
\text { November- }\end{array}$ & 50.00 & 14.08 & 11.27 & 2.82 & 63.38 & 11.27 \\
$\begin{array}{l}\text { December 2017 } \\
\text { April-May 2019 }\end{array}$ & 67.83 & 15.38 & 11.89 & 2.10 & 53.85 & 9.79 \\
November- & 53.68 & 20.59 & 12.50 & 2.94 & 58.09 & 8.09 \\
December 2020 & 53.96 & 15.11 & 9.35 & 0.72 & 51.80 & 9.35 \\
\hline
\end{tabular}

will make it possible to increase the technological independence of the Russian economy through import substitution. On the other hand, this will give the opportunity of increasing the rate of economic growth due to the advanced development of the national engineering industry.

As for the purchases of machinery and equipment, the frequency of reports on the purchase of new domestic equipment in 2020 again exceeded the frequency of reports on the purchase of new equipment from the far abroad (Table 11). This is generally a pleasant fact, but it is largely due to the recent depreciation of the ruble and the rise in the cost of imports.

Meanwhile, the assessments of Russian enterprises in relation to the quality of domestic equipment unfor- tunately did not improve in 2020 . Only $7.26 \%$ of the respondents considered that the quality of Russian machinery and equipment had improved in most cases (Table 12).

Only $11.81 \%$ of enterprises reported that there was a lot of domestic equipment on the market that was not inferior in quality to foreign alternatives (Table 13). In addition, the share of answers that the gap in quality between Russian and foreign technology is decreasing turned out to be less than the share of answers about an increase in this gap, $15.20 \%$ compared to $28.00 \%$ (Table 14 ).

As part of the survey, a study was also carried out on the situation with the terms of the delivery of raw materials and components to Russian enterprises. The 
Table 12. Answers to the question: "Has the quality of Russian machinery and equipment improved?" (total of answers $=100 \%)$

\begin{tabular}{l|c|c|c|c}
\hline \multicolumn{1}{c|}{ Period } & $\begin{array}{c}\text { Yes, it has improved } \\
\text { in most cases }\end{array}$ & $\begin{array}{c}\text { It has improved for some } \\
\text { types and has remained } \\
\text { at the same level for others }\end{array}$ & $\begin{array}{c}\text { It has in general } \\
\text { remained } \\
\text { at the same level }\end{array}$ & $\begin{array}{c}\text { The quality has } \\
\text { in general worsened }\end{array}$ \\
\hline February-March 2010 & 8.12 & 34.38 & 26.25 & 21.25 \\
October-December 2011 & 6.62 & 38.24 & 48.53 & 6.62 \\
April-May 2013 & 7.59 & 31.03 & 46.21 & 5.17 \\
November-December 2014 & 8.80 & 31.20 & 56.00 & 3.60 \\
April-May 2016 & 7.91 & 35.25 & 53.24 & 5.07 \\
November-December 2017 & 18.12 & 33.33 & 48.85 & 6.87 \\
April-May 2019 & 10.69 & 33.59 & 52.42 & 7.26 \\
November-December 2020 & 7.26 & 33.06 & & \\
\hline
\end{tabular}

Table 13. Answers to the question: "Do Russian-made machinery and equipment needed for your company include such models that are not inferior in quality to their counterparts from the far abroad?" (total of answers = $100 \%)$

\begin{tabular}{l|c|c|c}
\hline \multicolumn{1}{c|}{ Period } & $\begin{array}{c}\text { Yes, and quite } \\
\text { a lot }\end{array}$ & $\begin{array}{c}\text { Yes, but very } \\
\text { little }\end{array}$ & No \\
\hline $\begin{array}{l}\text { February-March } \\
2010\end{array}$ & 6.25 & 51.88 & 41.87 \\
$\begin{array}{l}\text { October-Decem- } \\
\text { ber 2011 }\end{array}$ & 6.34 & 54.93 & 38.73 \\
April-May 2013 & 6.08 & 50.00 & 43.92 \\
November- & 3.85 & 53.08 & 43.07 \\
$\begin{array}{l}\text { December 2014 } \\
\text { April-May 2016 }\end{array}$ & 10.42 & 58.33 & 31.25 \\
$\begin{array}{l}\text { November- } \\
\text { December 2017 }\end{array}$ & 12.75 & 50.34 & 36.91 \\
April-May 2019 & 14.71 & 47.06 & 38.23 \\
November- & 11.81 & 50.39 & 37.80 \\
December 2020 & & & \\
\hline
\end{tabular}

survey data show that at present the vast majority of enterprises do not face significant problems caused by violations in delivery terms.

Almost $80 \%$ of the respondents noted that delivery terms were almost never violated or rarely violated (Table 15). Meanwhile, it should be noted that the share of violations in deliveries that occurred through the fault of transport workers is extremely low, being $5.51 \%$ of answers (Table 16). These data can be considered as an indirect confirmation of the very efficient operation of the modern Russian transport system. It should also be noted that the overwhelming majority of enterprises believe that delays in deliveries usually do not lead to a significant increase in their costs (Table 17).

As a follow-up to the previous surveys on sustainable development, the state of affairs in the field of environmental modernization of Russian enterprises was investigated and the problem of using the best available technologies (BAT) was raised. The introduction of BAT is provided for by international conventions and agreements that were also ratified in Rus$\mathrm{sia}^{2}$ and is an important institutional mechanism aimed both at reducing the negative impact on the environment from industrial enterprises and at modernizing their production facilities.

While the concept of the best available technologies began to take root in Europe and North America in the $1980 \mathrm{~s}^{3}$, a similar concept in Russia-the best available technologies-was first established only in $2002^{4}$, although this concept was present in an implicit form in a number of GOSTs on resource conservation, rationing of material costs and other areas. In fact, the process of transferring production to the BAT began in 2014, when the federal law of July 21, 2014, No. 219-FL was adopted, according to which enterprises are required to introduce economically rational technologies that minimize wastes and emissions.

Due to the fact that the BAT principles have been introduced into Russian practice relatively recently, not all Russian industrial enterprises are familiar with this concept. The results of the survey have revealed that $40 \%$ of the surveyed enterprises do not know anything about the task of transition to the BAT (Fig. 1). Meanwhile, the real task of transition to the BAT is faced by $13.85 \%$ of enterprises, and almost a quarter of the surveyed enterprises expect such requirements to arise in the future.

About half of the surveyed enterprises (58\%) noted a number of expected positive consequences due to the

\footnotetext{
${ }^{2}$ Such as the Basel Convention on the Control of Transboundary Movements of Hazardous Wastes and Their Disposal, the Stockholm Convention on Persistent Organic Pollutants, etc.

3 The concept of BAT was first introduced in 1984 in the European Economic Community Directive No. 84/360/EEC concerning the abatement of air pollution from industrial plants [13].

${ }^{4}$ In Federal Law, On Environmental Protection, dated January 10, 2002, No. 7-FL.
} 
Table 14. Answers to the question: "How do you assess the size of the gap between the quality of machinery and equipment of Russian and foreign production in recent years?" (total of answers $=100 \%$ )

\begin{tabular}{l|c|c|c}
\hline \multicolumn{1}{c|}{ Period } & $\begin{array}{c}\text { In recent years the gap } \\
\text { in quality has been decreasing }\end{array}$ & $\begin{array}{c}\text { The gap remains about } \\
\text { at the same level }\end{array}$ & $\begin{array}{c}\text { The gap in quality continues to grow } \\
\text { in favor of imported equipment }\end{array}$ \\
\hline February-March 2010 & 15.72 & 36.48 & 47.80 \\
October-December 2011 & 12.95 & 50.36 & 36.69 \\
April-May 2013 & 10.74 & 53.69 & 35.57 \\
November-December 2014 & 16.80 & 60.00 & 23.20 \\
April-May 2016 & 18.18 & 55.94 & 25.88 \\
November-December 2017 & 28.47 & 52.78 & 18.75 \\
April-May 2019 & 20.15 & 54.48 & 25.37 \\
November-December 2020 & 15.20 & 56.80 & 28.00 \\
\hline
\end{tabular}

Table 15. Answers to the question: "How often are the terms of delivery of raw materials and components for your enterprise violated?" (total of answers $>100 \%$ )

\begin{tabular}{l|c|c|c|c|c}
\hline \multicolumn{1}{c|}{ Period } & Almost never & $\begin{array}{c}\text { Rarely (less than } \\
\text { in 10\% of cases) }\end{array}$ & $\begin{array}{c}\text { Not very often } \\
\text { (in 10-25\% of cases) }\end{array}$ & $\begin{array}{c}\text { Often (in 26-50\% } \\
\text { of cases) }\end{array}$ & $\begin{array}{c}\text { Very often (in more } \\
\text { than 50\% of cases) }\end{array}$ \\
\hline $\begin{array}{l}\text { November- } \\
\text { December 2020 }\end{array}$ & 31.82 & 47.73 & 16.67 & 3.03 & 0.76 \\
\hline
\end{tabular}

Table 16. Answers to the question: "Whose fault is the delivery terms being violated?" (total of answers $>100 \%$ )

\begin{tabular}{c|c|c|c|c}
\hline Period & $\begin{array}{c}\text { Through the fault } \\
\text { of suppliers }\end{array}$ & $\begin{array}{c}\text { Through the fault } \\
\text { of transport workers }\end{array}$ & $\begin{array}{c}\text { Due to force majeure circumstances (international } \\
\text { sanctions, pandemic, changes in legislation, etc.) }\end{array}$ & Other \\
\hline $\begin{array}{l}\text { November- } \\
\text { December 2020 }\end{array}$ & 47.24 & 5.51 & 44.88 & 2.36 \\
\hline
\end{tabular}

Table 17. Answers to the question: "To what extent do today's delays of deliveries increase the costs of your company?" (total of answers $=100 \%$ )

\begin{tabular}{c|c|c|c|c}
\hline Period & $\begin{array}{c}\text { They barely } \\
\text { increase costs }\end{array}$ & $\begin{array}{c}\text { They increase costs, } \\
\text { but not significantly }\end{array}$ & $\begin{array}{c}\text { They increase costs } \\
\text { significantly }\end{array}$ & $\begin{array}{c}\text { They increase costs } \\
\text { critically }\end{array}$ \\
\hline November-December 2020 & 34.92 & 51.59 & 12.70 & 0.79 \\
\hline
\end{tabular}

introduction of the BAT system: the opportunity of zeroing fees for negative environmental impact $(32.10 \%)$ and a real reduction in the burden on the environment $(30.86 \%)$ were most frequently mentioned (Fig. 2).

At the same time, an even greater part of the surveyed enterprises $(64 \%)$ noted the possible negative consequences that they may face in the event of the introduction of the BAT system: one third of enterprises feared that additional costs were not justified in relation to real environmental effects; the second third feared an excessive increase in the cost of production; the third one feared a further increase in the bureaucratic burden (Fig. 3). Some of the respondents apprehended the growth of investment costs in a short time and difficulties in developing their own systems. The respondents also included the enterprises that did not see any negative consequences from the introduction of the BAT, but such enterprises turned out to be a minority.

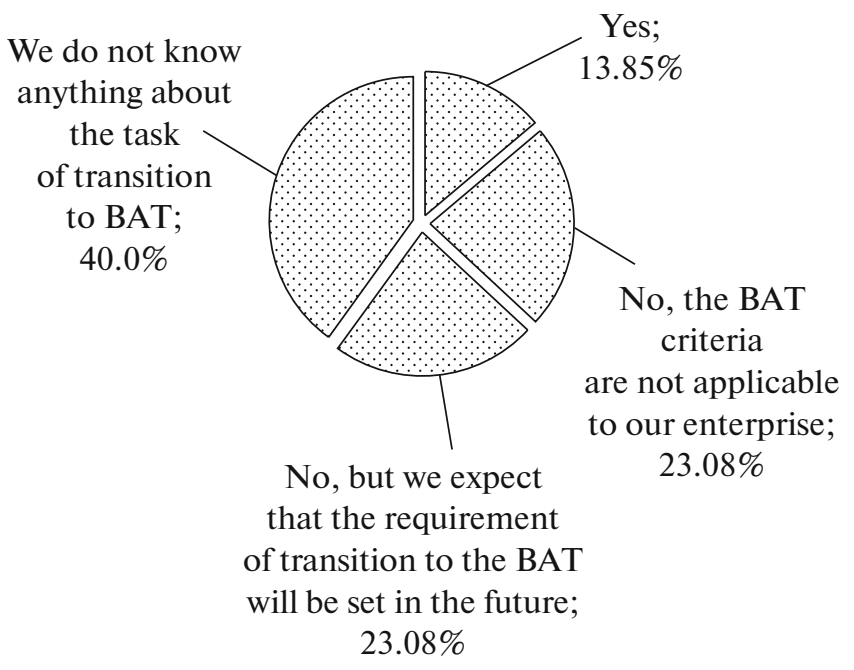

Fig. 1. Answers to the question: "Has your enterprise been assigned a task of transition to the best available technologies (BAT) in accordance with Order of the Government of the Russian Federation as of March 19, 2014 No. 398-r?" 


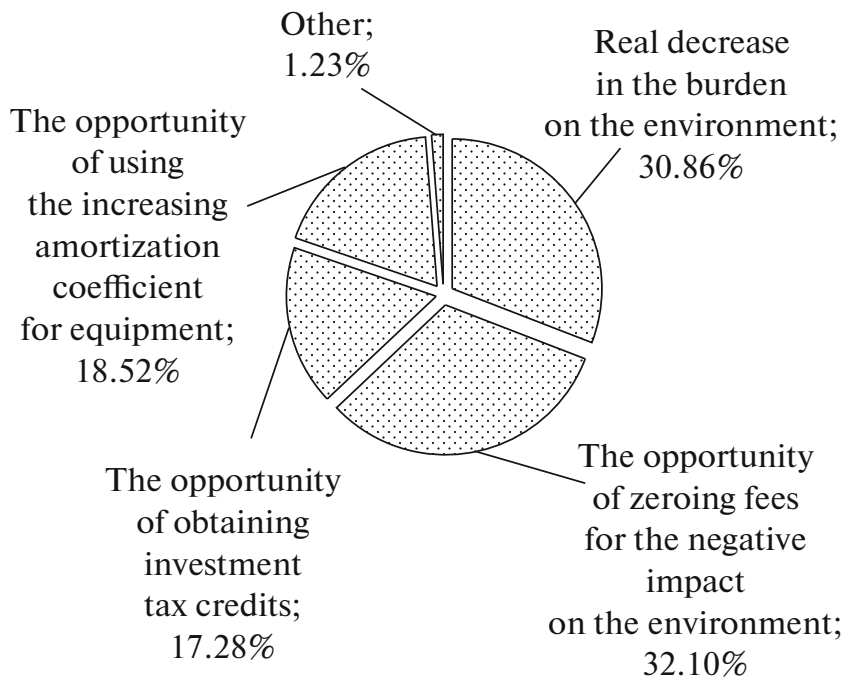

Fig. 2. Answers to the question: "Indicate what positive consequences for your company you expect due to the implementation of the BAT system according to Decree No. 398-r".

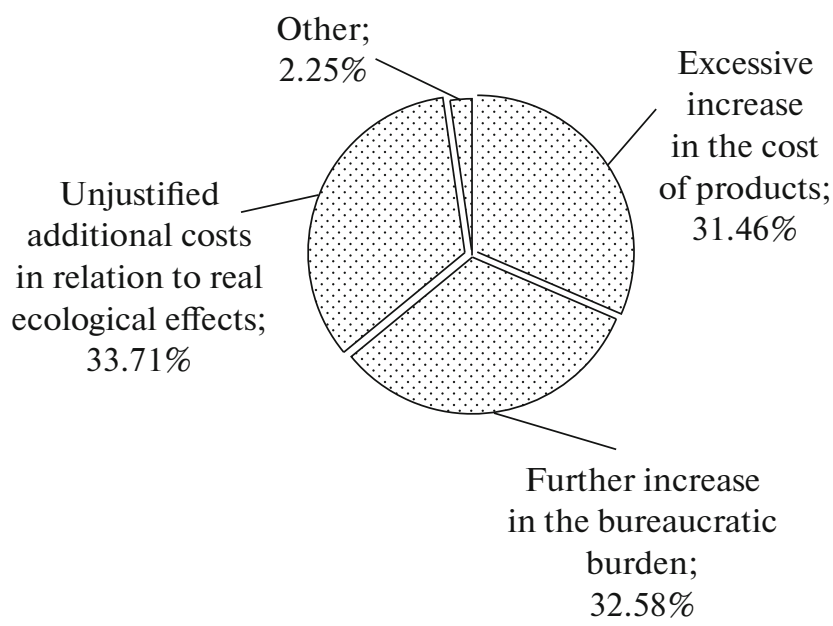

Fig. 3. Answers to the question: "Indicate what negative consequences for your company do you expect in the event of the introduction of the BAT system".

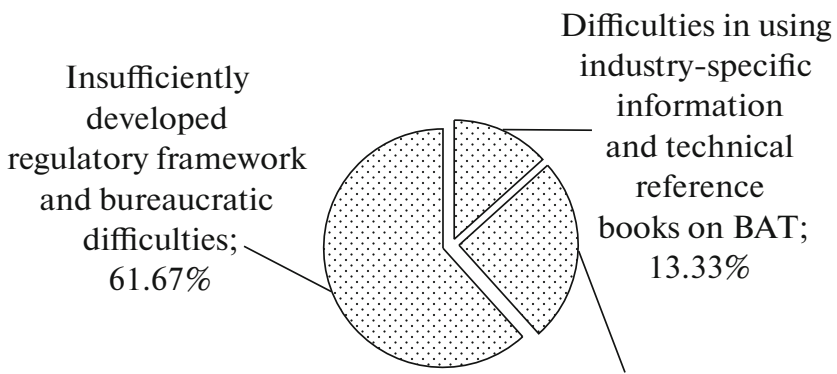

Difficulties in calculating specific indicators of production efficiency according to BAT reference books; $25.00 \%$

Fig. 4. Answers to the question: "What difficulties does your enterprise face during the transition to the BAT system?"
It should be noted that all surveyed enterprises, which have been assigned the task of transition to the BAT, as well as some enterprises that expect this task to be set in the future, face difficulties in the process of their implementation. Of the surveyed enterprises, $61.67 \%$ saw difficulties in an insufficiently developed regulatory and legal mechanism and bureaucratic difficulties, $25 \%$ of enterprises face difficulties in calculating specific indicators of production efficiency according to BAT reference books, and $13.33 \%$ of enterprises have difficulties in using industry-specific information and technical reference books on the BAT (Fig. 4).

The Russian BAT system is largely based on the experience of foreign countries in this area, since it involves the harmonization of legislation in the field of environmental protection and public health with the international one ${ }^{5}$, but at the same time it has its own characteristics and significant differences. The most significant difference is that the Russian BAT system lacks a comprehensive approach to environmental impact management: permits are issued not for all types of negative impact, but only for emissions and discharges of pollutants.

In this regard, it is important to understand to what extent Russian enterprises are ready for possible further harmonization of the Russian legislation with the international norms. About half of the surveyed enterprises found it difficult to answer this question. But, despite the difficulties of the enterprises in the process of transition to the BAT systems, almost one third of enterprises still believe that the BAT system should be expanded and its influence must also be extended to the regulation of industrial waste and limits on its disposal (Table 18).

The conclusions from the survey are as follows:

1. The COVID-19 pandemic continues to negatively affect the situation in the Russian economy; however, in general, the severity of the economic crisis in the country had decreased by the end of 2020. At the same time, the share of Russian enterprises that managed to receive anticrisis assistance from the federal authorities had increased significantly by the end of 2020 .

2. Russian enterprises still consider that the most significant macroeconomic problems for themselves are insufficient effective demand from consumers, high taxation, lack of quality labor and high prices for energy and transport.

3. Despite the crisis, the relations between Russian enterprises and banks as a whole have not deteriorated.

4. The frequency of purchases of Russian machinery and equipment in 2020 has again outstripped the

\footnotetext{
${ }^{5}$ In particular, Federal Law No. 219 was formed taking into account the EU and Council Directive 2010/75/EU dated November 24, 2010, On Industrial Emissions (Comprehensive Prevention and Control), and the European Parliament and Council Directive 2008/1/EC dated January 15, 2008, On Integrated Prevention and Control of Pollution.
} 
Table 18. Answers to the question: "Do you consider it expedient within the framework of the BAT system to introduce control not only for emissions and discharges of pollutants, but also for the formation of industrial waste and the receipt of limits on its disposal?"

\begin{tabular}{l|c|c|c}
\hline \multicolumn{1}{c|}{ Period } & Yes & No & It is difficult to answer \\
\hline $\begin{array}{l}\text { November-December } \\
2020\end{array}$ & 32.14 & 19.05 & 48.81 \\
\hline
\end{tabular}

frequency of purchases of machinery and equipment from the far abroad. However, Russian enterprises still rate the quality of domestic equipment rather low.

5. The situation with the supply of raw materials and components to Russian enterprises looks quite good. In general, delivery terms are not often violated.

6. A significant part of enterprises are not familiar with the task of transition to the BAT principles and do not have a clear opinion about their further development in Russia.

7. Many Russian enterprises express concern about the possible negative consequences of the introduction of the BAT systems.

8. Nevertheless, many surveyed enterprises have a positive attitude to the implementation of the BAT systems and consider it important to further harmonize the Russian legislation in this area with the international legal norms.

\section{ACKNOWLEDGMENTS}

G.P. Belyakova, L.I. Pisareva, N.I. Titova, R.A. Galetskaya, and $\mathrm{O}$. Yu. Galetskaya took part in preparing the article.

\section{FUNDING}

The article was prepared within the framework of the Program of fundamental scientific research of state academies of sciences, theme No. 168.6 "Research of Microeconomic Processes (Monitoring, Analysis, and Forecast).”

\section{REFERENCES}

1. A. Shirov, "Corona crisis as a challenge for economic policy," Vedomosti, Dec. 29 (2020). https://www.vedomosti. ru/opinion/articles/2020/12/29/853008-vosstanavlivatsya-rost.

2. The World Bank Improved the Negative GDP Growth Forecast for Russia in 2020. https://tass.ru/ekonomika/ 10270561.

3. The Ministry of Economic Development Improved the Negative GDP Growth Forecast for Russia in 2020 to 3.8\%. https://tass.ru/ekonomika/10351705.

4. Federal State Statistics Service of Russia. Socio-Economic Situation in Russia-2020. https://rosstat.gov.ru/ bgd/free/B20_00/Main.htm.

5. N. I. Komkov, "External and internal challenges and prospects for the modernization of Russia's economy," MIR (Modernizatsiya, Innovatsii, Razvit.) 9 (1), 1224 (2018).

6. N. I. Komkov, Problems of Managing the Development of Large-Scale Socio-Economic Systems (Nauka, Moscow, 2020) [in Russian].

7. N. I. Komkov, "Conditions of the structural and innovation policy for the development of the Russian economy," MIR (Modernizatsiya. Innovatsii. Razvitie) 89 (1), 80-87 (2017).

8. Yu. V. Yaremenko, "Priority to structural and technological renewal of the national economy," Ross. Ekon. Zh., No. 1, 3-7 (1994).

9. A. A. Blokhin and A. G. Fonotov, "Global traps for the Russian innovation system," Mir Nov. Ekon. 14 (2), 51-62 (2020).

10. V. N. Borisov and O. V. Pochukaeva, "Method for assessing the process of import substitution in the Russian market of investment equipment and its statistical support," Vestn. Novosib. Gos. Univ. Ekon. Upr., No. 3, 94-108 (2019).

11. V. Borisov and O. Pochukaeva, "Russian market of investment equipment: Stagnation or development," O-vo. Ekon., No. 12, 59-74 (2019).

12. I. A. Budanov, A. Yu. Kolpakov, D. A. Polzikov, et al., Economic Aspects of Modernization of the Waste Management Sector in Russia. Scientific Report (Nauka, Moscow, 2020) [in Russian].

13. Council Directive 84/360/EEC of 28 June 1984 on the Combating of Air Pollution from Industrial Plants. https://eur-lex.europa.eu/eli/dir/1984/360/oj. Accessed December 30, 2020.

Translated by L. Solovyova 